\title{
Analysis of Residual Tritium in an LP 50 Product Container
}

by

D. M. Hasty (Contact)

Westinghouse Savannah River Company

Savannah River Site

Aiken, South Carolina 29808

J. R. Wermer

This paper was prepared in connection with work done under the above contract number with the U. S. Department of Energy. By acceptance of this paper, the publisher and/or recipient acknowledges the U. S. Government's right to retain a nonexclusive, royalty-free license in and to any copyright covering this paper, along with the right to reproduce and to authorize others to reproduce all or part of the copyrighted paper. 


\section{DISCLAMMER}

Portions of this document may be illegible in electronic image produets. Images are produced from the best available original document. 


\section{DISCLATMER}

This report was prepared as an account of work sponsored by an agency of the United States Government. Neither the United States Government nor any agency thereof, nor any of their employees, makes any warranty, express or implied, or assumes any legal liability or. -responsibility for the accuracy, completeness, or usefulness of any information, apparatus, product, or process disclosed, or represents that its use would not infringe privately owned rights. Reference herein to any specific commercial product, process, or service by trade name, trademark, manufacturer, or otherwise does not necessarily constitute or imply its endorsement, recommendation, or favoring by the United States Government or any agency thereof. The views and opinions of authors expressed herein do not necessarily state or reflect those of the United States Government or any agency thereof.

This report has been reproduced directly from the best available copy.

Available to DOE and DOE contractors from the Office of Scientific and Technical Information, P.O. Box 62, Oak Ridge, TN 37831; prices available from (615) 576-8401.

Available to the public from the National Technical. Information Service, U.S. Department of Commerce, 5285 Port Royal Road, Springfield, VA 22161. 
WSRC-TR-96-0107

Revision 1

page 1 of 8

\section{Analysis of Residual Tritium in an LP50 Product Container}

June 4, 1996

J. R. Wermer

Savannah River Technology Center

Westinghouse Savannah River Company

Savannah River Site

Aiken, SC

\section{Summary}

The residual tritium in a LP50 tritium Product Container (PC) was analyzed by sampling coupons cut from the side of the vessel. Tests were perform to analyze the amount of residual tritium in the container wall, as well as the amount of tritium removed through exposure to moist air. Based on this data, the PC contained 62 curies (Ci) of residual tritium. Air exposure and leaching of the coupons in water accounted for 35 curies; dissolution of the coupons in aqua regia accounted for 27 curies. Specific recommendations are given in this report for final processing of these containers in order to reduce the final tritium content.

\section{Introduction}

The LP50 Product Container (PC) has been used to ship tritium around the country since the 1950's. When the DOT certification of these containers expired in 1995, they were removed from service. These containers are now being prepared for disposal. In this study, a section of one of these containers, \#624, was sampled in order to determine the residual tritium content. This particular container was selected because the recent shipping history included a large number of high purity tritium shipments.

The LP50 Product container is fabricated from type 304 stainless steel. It has an internal volume of slightly less than fifty liters. The ID of the container is 13 in., the height of the vessel is 26.5 inches, and the wall thickness is 0.078 in. The total weight of the vessel is approximately $28 \mathrm{lb}$., with about $1 \mathrm{lb}$. of the weight in the Hoke bellows-seal valve. 
WSRC-TR-96-0107

Revision 1

Page 2 of 8

The vessel is nearly cylindrical; the bottom and top are slightly concave and convex, with respect to the body of the cylinder. The internal surface area was approximated considering the container to be a cylinder $13 \mathrm{in}$. in diameter and $26.5 \mathrm{in}$. high. This gives an internal surface area of 1350 square inches.

The PC's were used for shipments of tritium--purities varied from a few per cent to pure tritium. Typical loading pressure was 1.0 atmosphere (760 torr), however, loading pressures up to 1.6 atmospheres (1200 torr) were allowed. The normal method of preparation for disposal is to evacuate the PC until the manifold pressure is $<130$ microns of mercury $(0.130$ torr) on the manifold thermocouple vacuum gauge (TCVG). Dynamic vacuum is maintained while the PC is heated to $120^{\circ} \mathrm{C}$ for an additional six hours. After this heating period, the isolation valve is closed and the PC is removed from the unloading manifold.

Product Container \#624 was fabricated on $1 / 57$. The volume of the container was determined to be 49.520 L. From 1957 until approximately 1993, it was used for shipments of high purity tritium. From 1993 until 1995 it was used for shipments of lower purity tritium from Mound Laboratory to the Savannah River Site. The final unloading was done on $12 / 95$.

\section{Experimental}

PC \#624 was removed from service, unloaded, and evacuated while heating to $120^{\circ} \mathrm{C}$. A final pressure on the unloading manifold of $<130$ microns of mercury ( 0.130 torr) was achieved. This was the normal preparation of this type of container for final disposal. It was removed from the manifold. It was then put on the manifold, evacuated, and backfilled with argon in 2/19/96 to a pressure of 1.0 atmosphere (760 torr). The isolation valve was closed, and the container was removed from the manifold. The container was allowed to stand for four days before the coupons were cut from the container wall.

Coupon Preparation. To obtain samples of the container walls, the operator first marked out a series of nine adjacent $1 " \times 1$ " squares on the side of the container and away from the seam weld. A positive pressure (relative to atmospheric pressure) of argon was applied to the vessel, and the operator drilled a series of pilot holes using a high speed twist drill. He then proceeded to cut three sides of each coupon using an electric saber saw with a metal cutting blade. Before the final cut was made the container was placed in a large asbestos control glovebag. The bag was inflated with argon, however, not purged for any 
WSRC-TR-96-0107

Revision 1

Page 3 of 8

length of time to remove residual oxygen. The final cuts on the first three samples (\#1-3) were made using a hacksaw. As soon as these coupons were free from the container, they were dropped in sample bottles containing $200 \mathrm{~mL}$ of deionized water. The LP50 container was then removed from the glovebag. The final cuts were made with the saber saw. These samples (A-C and 4-6) were placed in a bag and transferred to Materials Test Facility hoods.

Measurement of Exchangeable Surface-Bound Tritium. During the cutting operation, a total of 19 curies of tritium (nearly $100 \%$ tritium oxide (HTO)) was lost from the container, as recorded on the $232-\mathrm{H}$ stack monitor and integrator. This was assumed to be due to exchange of surface bound tritium by moisture. After transfer to the MTF hoods, samples $\mathrm{A}, \mathrm{B}$, and $\mathrm{C}$ were placed in polyethylene sample containers after 75 minutes. Samples 4,5 , and 6 were left in the hood for several days before they were polished using a Scotchbrite ${ }^{\mathrm{TM}}$ scouring pad.

The water from samples $1,2,3, \mathrm{~A}, \mathrm{~B}$, and $\mathrm{C}$ was diluted to $1000 \mathrm{~mL}$, sampled, and counted using liquid scintillation counting methods to determine the tritium content.

\section{Determination of Weights and Dimensions}

The samples which had been soaked in water were allowed to dry. Measurements were made on the four edges of each coupon using a micrometer. Each coupon was also weighed on an analytical balance. Samples 4, 5, and 6 were weighed and measured after polishing with a Scotchbrite ${ }^{\mathrm{TM}}$ pad

Coupon Dissolution. Coupon \# 1 was placed in an open polystyrene beaker. To this beaker $20 \mathrm{~mL}$ of concentrated nitric acid (35 wt. \%) and $20 \mathrm{~mL}$ of concentrated hydrofluoric acid (48 wt. \%) were added. Little reaction was noted. After 10 minutes, $20 \mathrm{~mL}$ of concentrated hydrochloric acid (37 wt. \%) was added. A vigorous reaction ensued. After approximately 20 minutes, the reaction had stopped, leaving a dark green solution. The liquid contents of the beaker were poured into a $1000 \mathrm{~mL}$ volumetric flask containing $300-400 \mathrm{~mL}$ of deionized water. The coupon had not completely dissolved, and appeared bright and shiny. The solution was further diluted to $1000 \mathrm{~mL}$. After mixing, samples of the solution were taken and counted using liquid scintillation counting methods to determine the tritium content.

The other coupons (\#2, 3, A, B, C, 4, 5, and 6) and the remnants of \#1 were dissolved as follows: The coupons were placed in open 
polystyrene beakers. To each beaker $20 \mathrm{~mL}$ of concentrated nitric acid (35 wt. \%) $20 \mathrm{~mL}$ of concentrated hydrochloric acid (37 wt. \%) was added. A vigorous reaction ensued. After approximately 20 minutes, the reaction had stopped, leaving a dark green solution. The liquid contents of the beaker were poured into a $1000 \mathrm{~mL}$ volumetric flask containing 300-400 $\mathrm{mL}$ of deionized water. The coupon had not completely dissolved, and appeared bright and shiny. The solution was further diluted to $1000 \mathrm{~mL}$. After mixing, samples of the solution were taken and counted using liquid scintillation counting methods to determine the tritium content. This dissolution described above was repeated three or four times until each coupon was completely dissolved.

The first dissolution attempt on coupon \#1 produced a much lighter green solution than the other attempts, indicating some passivation by the hydrofluoric acid.

Some hood air tritium activity was noted during dissolution of the coupons, but this was quite small. No attempts were made to correlate this activity with the tritium content of the coupons.

\section{Results}

Weight and Surface Area Determinations. The weight and the estimated bulk surface area of each coupon is given in the table below. The surface area was approximated by multiplying the average of the two opposite edges. For example, in the drawing below, the surface area of this coupon is given as $\left(\frac{A+C}{2}\right)\left(\frac{B+D}{2}\right)$ where $A, B, C$, and D are the edge lengths:

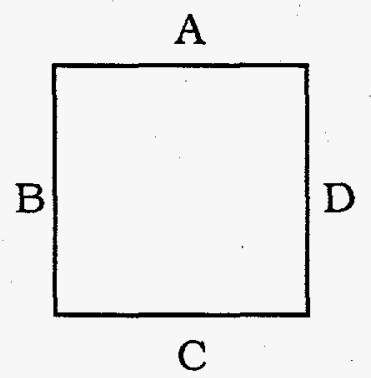


WSRC-TR-96-0107

Revision 1

Page 5 of 8

\begin{tabular}{|l||c|c|c|c|c|c|c|c|c|}
\hline Coupon \# & $\mathbf{1}$ & $\mathbf{2}$ & $\mathbf{3}$ & $\mathbf{A}$ & $\mathbf{B}$ & $\mathbf{C}$ & $\mathbf{4}$ & $\mathbf{5}$ & $\mathbf{6}$ \\
\hline \hline Edge A & 1.004 & 1.140 & 1.008 & 0.990 & 0.973 & 0.964 & 0.999 & 0.927 & 0.998 \\
\hline Edge C & 0.943 & 1.036 & 0.964 & 0.991 & 1.003 & 1.021 & 1.013 & 1.028 & 0.998 \\
\hline Edge B & 1.014 & 1.030 & 1.013 & 1.001 & 0.966 & 0.966 & 1.007 & 0.943 & 0.987 \\
\hline Edge D & 0.944 & 1.078 & 0.971 & 0.935 & 1.016 & 0.977 & 1.000 & 1.017 & 1.017 \\
\hline Surface Area & 0.953 & 1.147 & 0.978 & 0.959 & 0.979 & 0.964 & 1.010 & 0.958 & 1.000 \\
\hline Weight & 8.962 & 10.461 & 9.214 & 8.838 & 9.244 & 9.329 & 9.539 & 8.998 & 9.403 \\
\hline
\end{tabular}

Table 1. Dimensional Measurements and Weights of the Test Coupons. All weights are in grams, edge measurements are in inches and surface areas are in square inches.

Water Leaching Experiment. The results of the water leaching test on samples 1,2, and 3 (placed in water immediately) and samples A, B, and $\mathrm{C}$ (placed in water after 75 minutes) are given below in Table 2 .

\begin{tabular}{|c||c|c|c|c|}
\hline $\begin{array}{c}\text { Coupon } \\
\#\end{array}$ & $\begin{array}{c}\text { Activity } \\
\text { (pCi/mL) }\end{array}$ & $\begin{array}{c}\text { Total Activity (Ci) } \\
\text { (for 1000 mL sample) }\end{array}$ & $\begin{array}{c}\text { Surface Area } \\
\text { sq. in. }\end{array}$ & $\begin{array}{c}\text { Ci/sq. in. of } \\
\text { surface area }\end{array}$ \\
\hline \hline $\mathbf{1}$ & $1.18 \mathrm{E}+7$ & $1.18 \mathrm{E}-2$ & 0.953 & $1.24 \mathrm{E}-2$ \\
\hline $\mathbf{2}$ & $1.30 \mathrm{E}+7$ & $1.30 \mathrm{E}-2$ & 1.147 & $1.13 \mathrm{E}-2$ \\
\hline $\mathbf{3}$ & $1.22 \mathrm{E}+7$ & $1.22 \mathrm{E}-2$ & 0.978 & $1.25 \mathrm{E}-2$ \\
\hline Mean & & & & $1.21 \mathrm{E}-2$ \\
\hline $\mathbf{A}$ & $6.88 \mathrm{E}+6$ & $6.88 \mathrm{E}-3$ & 0.959 & $7.17 \mathrm{E}-3$ \\
\hline $\mathbf{B}$ & $9.18 \mathrm{E}+6$ & $9.18 \mathrm{E}-3$ & 0.979 & $9.37 \mathrm{E}-3$ \\
\hline $\mathbf{C}$ & $8.43 \mathrm{E}+6$ & $8.43 \mathrm{E}-3$ & 0.964 & $8.74 \mathrm{E}-3$ \\
\hline Mean & & & & $8.43 \mathrm{E}-3$ \\
\hline
\end{tabular}

Table 2. Tritium activity from water leaching experiment.

The results included in Table 2 do not take into account the loss to the exhaust stack (19 Ci) during the cutting operation (see Discussion). 
WSRC-TR-96-0107

Revision 1

Page 6 of 8

Coupon Dissolution. Results from counting of the dissolved coupons is given below. Dilution of the aqua regia $\left(\mathrm{HNO}_{3} / \mathrm{HCl}\right.$ mixture) solution resulted in light green solutions. No interference was found with the colored species in the liquid scintillation counter (LSC) was found. The results of the LSC counting is shown below in Table 3.

\begin{tabular}{|c||c|r|r|r|c|}
\hline & $\begin{array}{c}\text { Run \#1 } \\
\text { (pCi/mL) }\end{array}$ & $\begin{array}{c}\text { Run \#2 } \\
\text { (pCi/mL) }\end{array}$ & $\begin{array}{c}\text { Run \#3 } \\
\text { (pCi/mL) }\end{array}$ & $\begin{array}{c}\text { Run \#4 } \\
\text { (pCi/mL) }\end{array}$ & $\begin{array}{c}\text { Total T } \\
\text { (Ci) }\end{array}$ \\
\hline \hline $\mathbf{1}$ & $5,657,478^{*}$ & $10,651,486$ & $1,975,640$ & & 0.0183 \\
\hline $\mathbf{2}$ & $24,004,324$ & $1,964,467$ & 278,460 & 31,763 & 0.0263 \\
\hline $\mathbf{3}$ & $13,912,401$ & $1,023,325$ & 124,722 & & 0.0151 \\
\hline $\mathbf{A}$ & $17,201,577$ & $1,304,507$ & 108,080 & & 0.0186 \\
\hline $\mathbf{B}$ & $18,546,820$ & $4,185,381$ & $1,133,368$ & 33,614 & 0.0239 \\
\hline $\mathbf{C}$ & $17,213,311$ & $3,031,766$ & 698,038 & & 0.0209 \\
\hline $\mathbf{4}$ & $22,244,941$ & $1,110,668$ & 83,655 & & 0.0234 \\
\hline $\mathbf{5}$ & $16,064,360$ & $2,924,035$ & 229,981 & & 0.0192 \\
\hline $\mathbf{6}$ & $17,271,964$ & $4,072,074$ & 405,092 & & 0.0217 \\
\hline
\end{tabular}

*Hydrofluoric acid was used in this attempt, apparently passivating the surface to some extent. Additional attempts on coupon \#1 were done with nitric/hydrochloric acid mixtures.

Table 3. Liquid Scintillation Counting results for dissolved coupons.

\section{Discussion}

Visual Appearance. The LP50 container was gray and appeared to be well oxidized. The coupons cut from the container appeared the same on both interior and exterior sides.

Surface Bound (Exchangeable) Tritium. The water leaching experiment was intended to show a difference between the unexposed (to air) surface of the container material and the result of air exposure to this surface. As seen in Table 1, there is a measurable difference between the two sets of samples. Based on this analysis, the average of samples 1, 2, and 3 (no air exposure after cutting) contributed 16.3 curies to the total. The average of samples A, B, and C (75 minute air exposure after cutting) was 11.4 curies.

The large amount of tritium lost during the cutting operation (19 Ci), however, leaves some doubt as to whether this value should be counted as surface bound tritium. Some of this $19 \mathrm{Ci}$ might also be attributed to gaseous tritium which was flushed into the container during the backfilling operation. Attempts to exclude air were crude, and it would 
WSRC-TR-96-0107

Revision 1

Page 7 of 8

not be expected that this technique would be highly effective, since the glovebag was not thoroughly purged with argon before use. To totally exclude air (moisture and oxygen) would have required that the entire operation be performed in a glovebag which had been purged with several volumes of inert gas.

The most conservative estimate for surface bound, exchangeable tritium from this experiment is the sum from leaching experiments for samples 1,2 and 3 (16 curies) and the total from the stack monitor (19 curies). This gives a total of 35 curies of exchangeable tritium. This gives a total exchangeable tritium content of $0.0259 \mathrm{Ci} / \mathrm{sq}$. in. of surface area.

Totals from Dissolution Studies. Total tritium determined from dissolving the coupons in aqua regia is shown below in Table 4:

\begin{tabular}{|c||c|c|c|c|}
\hline $\begin{array}{c}\text { Coupon } \\
\#\end{array}$ & $\begin{array}{c}\text { Weight } \\
\text { (grams) }\end{array}$ & $\begin{array}{c}\text { Surface Area } \\
\text { (sq. in.) }\end{array}$ & $\begin{array}{c}\text { Total Tritium } \\
\text { (Ci) }\end{array}$ & Ci/gram \\
\hline \hline $\mathbf{1}$ & 8.962 & 0.953 & 0.0183 & 0.00204 \\
\hline $\mathbf{2}$ & 10.461 & 1.147 & 0.0263 & 0.00251 \\
\hline $\mathbf{3}$ & 9.214 & 0.978 & 0.0151 & 0.00164 \\
\hline $\mathbf{A}$ & 8.838 & 0.959 & 0.0186 & 0.00210 \\
\hline $\mathbf{B}$ & 9.244 & 0.979 & 0.0239 & 0.00259 \\
\hline $\mathbf{C}$ & 9.329 & 0.964 & 0.0209 & 0.00224 \\
\hline $\mathbf{4}$ & 9.539 & 1.010 & 0.0234 & 0.00245 \\
\hline $\mathbf{5}$ & 8.998 & 0.958 & 0.0192 & 0.00213 \\
\hline $\mathbf{6}$ & 9.403 & 1.000 & 0.0217 & 0.00231 \\
\hline Mean & 9.432 & 0.994 & 0.0208 & 0.00222 \\
\hline ST. Dev. & & & & 0.000290 \\
\hline
\end{tabular}

Table 4. Total Tritium from etching and dissolution of the coupons in aqua regia.

Based on the mean valve and the LP50 weight of $27 \mathrm{lb}(12,270 \mathrm{~g}), 27.2$ curies is held up in the vessel wall. As seen from the Table 4, most of this tritium is in the outer layer since it was removed in the first dissolution attempt. 


\section{WSRC-TR-96-0107 \\ Revision 1 \\ Page 8 of 8}

\section{Conclusions}

Analysis of the coupons from LP50 Container \#624 shows that it contains 62 curies of tritium. Much of this came from surface exchange with room air and water. The total surface exchangeable tritium was $0.0259 \mathrm{Ci}$./sq. in. of internal surface area. The remainder of the tritium came from etching and dissolution of the bulk metal with acid: The finish on PC \#624 was well oxidized (gray) and would be expected to hold more residual tritium than polished or machined surfaces.

\section{Recommendations}

Additional tritium could be removed from this container by the addition of moisture (a small of water added through the fill stem) and higher temperature $\left(>300^{\circ} \mathrm{C}\right)$ vacuum bakeout prior to removal from the manifold. If it is necessary to remove additional residual tritium, the following method is recommended.

1. After the normal heated evacuation procedure (i.e. $120^{\circ} \mathrm{C},<130$ microns), close the isolation valve and remove the $\mathrm{PC}$ from the manifold.

2. Fill the stem on the $\mathrm{PC}$ with $3-5 \mathrm{~mL}$ of deionized water.

3. Open the isolation valve briefly to admit the water and a small quantity of air.

4. After two weeks or longer, repeat the vacuum evacuation. A higher temperature $\left(>300^{\circ} \mathrm{C}\right)$ would greatly improve tritium removal from the container.

Additional sampling would be required to test the effectiveness of this method. 
cc: J. R. Knight, 773-A

R. A. Pedde, 235-H

P. J. Breidenbach, 235-H

T. Motyka, 773-A

D. Hasty, 232-H

B. D. Smith, 232-H

B. C. Rogers, 235-H

W. A. Gearman, 232-H

R. L. Rabun, 232-H

W. L. West, 773-A

P. J. Rowan, 233-26H

G. J. Alexander, 235- $\mathrm{H}$

C. R. Johnson, 234-H 